This is an Accepted Manuscript of an article published by Taylor \& Francis in Israel Affairs on 24 Aug 2018, available online: https://www.tandfonline.com/doi/full/10.1080/13537121.2018.1505687.

\title{
The Oslo Peace Process: Interview with Joel Singer
}

\section{Raphael Cohen-Almagor}

Israel Affairs (September 2018).

\section{Abstract}

This article records my interview with one of the authors of the Oslo Accords: Joel Singer who was brought to the negotiations from Washington at a later stage of the negotiations. The Oslo channel was established by Yossi Beilin, Terje Rød-Larsen and Yoel Hirschfeld who understood Yassir Arafat's need to initiate a new path for relationships with Israel. At that time, negotiations with the Palestinian Liberation Organization (PLO) were illegal. The PLO was regarded as a terrorist organization and the Israeli government refused to officially negotiate with Arafat, although it was clear to them that he was still the most capable person to strike a deal, and the only true representative of the Palestinian people. Bilateral negotiations begun in Washington between Israel and Palestinians who were supposedly independent of the PLO while everyone knew they were not. As mentioned above, these talks led to nowhere. This is Singer's version of this peace chapter. The article assesses the positive and negative aspects, lessons and implications of the process and of the Oslo Accords.

\section{Introduction}

For the past few years I am researching the failed peace process between Israel and the PLO, from Oslo 1993 until present time. Regarding Oslo I investigate how three outsiders - two academics ${ }^{1}$ and a Washington lawyer, represented Israel in the most important peace talks with the Palestinians, what were the pros and cons of the

\footnotetext{
1 Yoel Hirschfeld and Ron Pundak fulfilled the dream of many political scientists: to impact and transform the politics of a nation.
} 
negotiations, Oslo achievements and misgivings. I also research how the conditions of peace were advanced and promoted via third-party mediation of a small country. My investigation brings together studies in the fields of diplomacy, role of small states and the Middle East peace process. Studying the Oslo channel is important in order to see to what extent it is possible to conduct Israeli-Palestinian peace talks without the direct involvement of the Americans. Can small countries assist in the peace mediation process in a way that would supplement, or even replace, the American peace initiatives?

This research is important as the Americans continue to fail in their mediation attempts. Indeed, the Oslo channel was opened at a time when the formal, nonsecretive negations between Israel and the Palestinians were stalled in Washington DC. Despite the considerable political, economic and diplomatic investments in the peace process, the United States was unable to bring the Israelis and the Palestinians to sign a comprehensive peace pact and to settle their bloody conflict. This failure has prompted the two sides to seek alternative frameworks for negotiations in Norway. However, while some progress has been made, peace is still a distant prospect.

There is some literature on Oslo with contrasting interpretations. ${ }^{2}$ My research project involves extensive literature review of historic documents (including the Oslo Accords; Israeli-Palestinian Interim Agreement on the West Bank and the Gaza Strip; the Gaza-Jericho Agreement; the Abu Mazen-Beilin Agreement); autobiographies and monographs of peace negotiators; ${ }^{3}$ journal and newspaper articles. It is supplemented

\footnotetext{
${ }^{2}$ Ron Pundak and Hilde Henriksen Waage: Ron Pundak, Secret Channel (Tel Aviv: Aliyat Hagag, 2013, Hebrew) and "From Oslo to Taba: What Went Wrong?", Survival, Vol. 43, No. 3 (2001) and Professor Waage's articles in the Bibliography. See also Yair Hirschfeld, Track-Two Diplomacy toward an IsraeliPalestinian Solution 1978-2014 (Washington: Woodrow Wilson Center Press and Johns Hopkins University Press, 2014).
}

\footnotetext{
${ }^{3}$ Many of those involved in the peace process wrote books about the negotiations from their own perspectives. These books include: Mahmoud Abbas, Through Secret Channels (London: Garnet Pub Ltd, 1997); Hanan Ashrawi, This Side of Peace: A Personal Account (NY: Touchstone, 1996); Yossi Beilin, The Path to Geneva (NY: RDV Books, 2004) and Touching Peace (London: Weidenfeld and Nicolson, 1999); Shlomo Ben-Ami, Scars of War, Wounds of Peace (London: Phoenix, 2005) and A
} 
with archival research and with dozens of semi-structured interviews with decisionmakers, diplomats and negotiators who were, indeed still are, involved in the peace process. The goal of the interviews is to unearth the historical processes that constituted the peace process. Evidence of people who were part of the process help identify the factors that move history forward. Interviewees sign consent forms. Audiotapes of interviews are transcribed. The text is sent to the interviewees for their authorization. These interviews are historical documents. Signed interview transcripts and archival data relating to previous work is stored on secure university servers and are backed up to an offsite location.

Front without a Rearguard (Tel Aviv: Yedioth Ahronoth, 2004, Hebrew); Martin Indyk, Innocent Abroad (NY: Simon and Schuster, 2009); Daniel C. Kurtzer, Scott B. Lasensky, William B. Quandt, Steven I. Spiegel, and Shibley Z. Telhami, The Peace Puzzle: America's Quest for Arab-Israeli Peace, 19892011 (Ithaca and Washington: Cornell University Press, in Collaboration with the United States Institute of Peace, 2013); Aaron David Miller, The Much Too Promised Land: America's Elusive Search for ArabIsraeli Peace (NY: Bantam, 2008); Sari Nusseibeh, Once Upon A Country: a Palestinian life (London: Halban, 2009); Shimon Peres, For the Future of Israel (Baltimore: Johns Hopkins University Press, 1998) and Battling for Peace: A Memoir (London: Weidenfeld and Nicolson, 1995); Yair Hirschfeld, Track-Two Diplomacy toward an Israeli-Palestinian Solution 1978-2014 (Washington: Woodrow Wilson Center Press and Johns Hopkins University Press, 2014); Ron Pundak, Secret Channel (Tel Aviv: Aliyat Hagag, 2013, Hebrew); Ahmed Qurie, Peace Negotiations in Palestine (London: I.B. Tauris, 2015), Negotiating Palestine: From the Second Intifada to Hamas' Electoral Victory (London: I.B. Tauris, 2013) and Beyond Oslo (London: I.B. Tauris, 2008); Itamar Rabinovich, Waging Peace: Israel and the Arabs, 1948-2003 (Princeton, N.J.: Princeton University Press, 2004); Dennis Ross, The Missing Peace (New York: Farrar, Straus and Giroux, 2004); Uri Savir, Peace First: A New Model to End War (San Francisco, CA: Berrett-Koehler Publishers, 2008) and The Process (New York: Vintage, 1999); Gilead Sher, The Israeli-Palestinian Peace Negotiations, 1999-2001: Within Reach (London: Routledge, 2006). 
I have employed similar methodology in previous studies, benefiting from experts' experiences on topics that are not well covered in the literature. ${ }^{4}$ I found that interviews often highlight issues that are not discussed, or not discussed enough in the literature. Conversation with experts sheds light on hidden subjects that one can easily miss when confined to libraries. Moreover, the interviews I have already conducted in Israel, Palestine, United Kingdom and the United States reveal that there is not one history but many histories. People who were in the same room perceive the situation in different ways. A classic Rashomon.

This article records one interview with one of the authors of the Oslo Accords: Joel Singer who was brought to the negotiations from Washington at a later stage. The Oslo channel was established by Yossi Beilin, Terje Rød-Larsen and Yoel Hirschfeld who understood Yassir Arafat's need to initiate a new path for relationships with Israel. The Intifada which erupted in 1987 constituted a threat to Arafat's leadership. He was surprised by the scale of the uprising which brought thousands of protesters to the streets to fight against the occupation. Arafat had no knowledge of what was coming. The rise of Hamas further threatened the Fatah reign in Gaza and the West Bank. Arafat felt that he was losing his grip on the Palestinian territories and was anxious to do something which would bring him to the center of attention. Moreover, his alliance with Saddam Hussein during the 1991 Gulf War undermined his position among the moderate Arab world. Arafat needed to reinforce his leadership among the Palestinian people.

Arafat also was well aware of the warming relationships between Israel and Jordan. He understood that King Hussein might soon become the second Arab leader, after Sadat, to sign a peace treaty with Israel. Egypt had signed the peace treaty without the Palestinians, and Arafat had little illusions that Hussein would insist to wait, or to coordinate with him steps leading to peace. He thought another peace pact would isolate him further.

${ }_{4}$ Most recently for my book Confronting the Internet's Dark Side: Moral and Social Responsibility on the Free Highway (NY and Washington DC.: Cambridge University Press and Woodrow Wilson Center Press, 2015). 
The collapse of the Soviet Union during the late 1980s left the international arena with only one powerful actor, the United States, that squarely aligned itself with Israel. Arafat could no longer count on the Soviet Union to serve as a balancing power against American interests. He understood the need to establish some ties with the United States.

The return of the Labour Party to power in the summer of1992 signalled a moment of change. Prime Minister Rabin wished to move away from containment to addressing the core of the Israeli-Palestinian conflict: the occupation. Shimon Peres explained that "We were not going to rule the Palestinians against their will. We were always looking for a way to liberate them from our occupation and to liberate ourselves as occupiers". ${ }^{5}$

At that time, negotiations with the Palestinian Liberation Organization (PLO) were illegal. The PLO was regarded as a terrorist organization and the Israeli government refused to officially negotiate with Arafat, although it was clear to them that he was still the most capable person to strike a deal, and the only true representative of the Palestinian people. Bilateral negotiations begun in Washington between Israel and Palestinians who were supposedly independent of the PLO while everyone knew they were not. As mentioned above, these talks led to nowhere. ${ }^{6}$ Below is Singer's version of this peace chapter.

Until now I conducted 27 interviews with Israeli, Palestinian, American and British decision-makers and negotiators and published a series of articles about the peace process and the keys for its success. ${ }^{7}$ To complete my research I intend to

\footnotetext{
5 Shimon Peres and Robert Littell, For the Future of Israel (Baltimore: Johns Hopkins Press, 1998): 83.

${ }^{6}$ Shimon Peres and Robert Littell, For the Future of Israel, p. 84.

${ }^{7}$ Some of these articles are: R. Cohen-Almagor, "The Failed Peace Process in the Middle East 19932011", Israel Affairs, Vol. 18, No. 4 (October 2012): 563-576; "Two-State Solution - The Way Forward", Annual Review of Law and Ethics, Vol. 20 (2012): 381-395; "Suggestions for Israeli-Palestinian Agreement”, New Directions (Kivunim Hadashim), No.30 (June 2014): 144-159 (Hebrew); “Parameters for Two State Solution”, Palestine-Israel Journal, Vol. 21, No.2 (2015): 112-119; "Resolvendo o Conflito Israelense-Palestino - uma Solução Bi-Estatal", Oriente-Se, Vol. 1 (February 2016): 72-79,
} 
interview Norwegian and Swedish peace intermediaries and to conduct research in the relevant archives in Oslo, Stockholm, Washington and Little Rock. These are important junctions for studying the search for peace in the Middle East.

\section{Interview with Joel Singer}

29 August 2014

Washington, D.C.

Prof. Cohen-Almagor: I start with the beginning. Tell me how it all began. What happened? You're sitting in Washington and suddenly you receive a phone call from I believe, Yossi Beilin. Was it Yossi Beilin?

Joel Singer: $\quad$ His assistant, talked for him.

Prof. Cohen-Almagor: Shlomo Gur?

Joel Singer: Shlomo Gur yeah.

Prof. Cohen-Almagor: So you receive a phone call from Shlomo Gur, who tells you what? And then what happens?

Joel Singer: $\quad$ Well, what he told me was that Shimon Peres and Yossi Beilin would want me to come to Israel to review a certain document and provide my opinion about the document. When I asked him about the details, and I had no hesitation, as I told you, when I came to Washington, DC, I came here, then just to spend some time in Washington waiting to come back and go into a higher

https://Inkd.in/eCMAZA7; "President Trump and the Israeli-Palestinian Conflict", E-International Relations (10 March 2017)

http://www.e-ir.info/2017/03/10/president-trump-and-the-israeli-palestinian-conflict/ 
position within the government so I was very happy when they ask me to come and look at something on a volunteering basis.

I was employed by this law firm (Sidley Austin). I asked Shlomo Gur, "What is this document that you want me to review?" He said, "I cannot say. I cannot tell you but when you come here, you will look at it, and provide your opinion." So I asked, "When do you want me to come?" He said, "Today, tomorrow." I said, "Okay." So I found an excuse, taking a short leave for a couple of days, and flew to Israel. This is how ...

Prof. Cohen-Almagor: Immediately? The following day or the next day yeah. Well, you call the travel agency, you ask whether there is a seat on a plane and the next day, I flew for a couple of days. You can do it if you don't have a trial session on that day. And so I came to Israel, this is how it started for me. For them, that had started earlier. They actually asked me to look at a draft of the declaration of principles, after they thought that the document was almost complete. There were some issues that were still subject to additional discussions but from their perspective, it was almost done.

Prof. Cohen-Almagor: Okay, so you came to Jerusalem, you met I believe, Hirschfeld and Pundak first?

Joel Singer: Hirschfeld came to see me in the hotel.

Prof. Cohen-Almagor: Hirschfeld came to see you in the hotel and then ...

Joel Singer: $\quad$ Gave me ...

Prof. Cohen-Almagor: $\quad \ldots$ they gave you the document?

Joel Singer: $\quad$ Brought me the document. But what I recall is that, he gave me a copy of the draft Oslo Agreement as well as other documents and they were all scrambled together, and they were all in English. 
Some of the documents included his impressions, opinions, and plans; while other documents reflected the agreed document with the PLO. But I couldn't see the borderline between the actually agreed document, the documents conveying his impressions of what he thought was agreed, and the documents containing his thoughts about what he planned to do next. And it was all written in a broken, Middle Eastern English so it was a bit difficult to understand what the hell they were talking about. So I needed an explanation and I got this explanation after I read the documents.

Prof. Cohen-Almagor: From?

Joel Singer: I was given approximately an hour to read the documents in the Hilton hotel where I was staying and then I walked to the then Foreign Ministry. And I met with Yossi Beilin, Ron Pundak and Yair Hirschfeld and they provided the background and explanations and then Uri Savir joined the meeting. Now, apart from Yossi Beilin, I didn't know any of them. I didn't know Uri Savir, Hirschfeld and Pundak. I had no idea who they were. The only one I knew very well was Yossi Beilin because as a former secretary of the government, I had seen him a lot.

Prof. Cohen-Almagor: Okay, so you got documents, what was your impression? Once you focused on the one particular document

Joel Singer: $\quad$ Obviously, I'm not remembering the exact feeling but it was a mixture of, "Wow, they're now talking with The PLO. Finally." What I had thought way, way, way back that should have been done, so finally, they're doing it. And as to the agreement, it was vague, it was all not clear and there was a discrepancy between what they explained the agreement said, and what I read in the document. And important things were missing. I cannot now remember whether it was what they said, or what was written there, but I had a vague impression that I wasn't sure what was going on, because the terminology used in the document and their 
manner of talking was so different from the normal language I was used to in international negotiations related to the West Bank and Gaza. They were talking mostly about economic cooperation and projects. They kept talking and I was thinking to myself: "We're talking about the PLO. When you negotiate an agreement with an enemy, there are so many other things to deal with. Economic cooperation, projects and fish ponds and agriculture, yes that's important but where is everything else that is much more important?" That was my feeling.

But then they said "Oh, they promised this, they promised that, they said so." I said, "But where is it written?" Some of it was written in documents that Hirschfeld had developed but not in the agreed documents. It was written in documents that Hirschfeld wrote in English. I didn't even understand why he wrote in English, and not in Hebrew, to the Foreign Ministry. It was bizarre to me. The whole event was a bit bizarre. And then they took me to meet with Shimon Peres and I said, "It's interesting, it's promising ..." I wanted to be diplomatic, so I put the best light on the promising side and I went back to the United States. And I was confident that I would never see them again. I thought it was so ...

Prof. Cohen-Almagor: So you stayed there for two days?

Joel Singer: Yeah.

Prof. Cohen-Almagor: You met with Shimon, what did you tell Shimon Peres?

Joel Singer: "Well, first of all, talking with The PLO is promising. That's the right way to go, and from what I hear about what the PLO representatives said, it's interesting, it's promising and yeah, nice job." And that's it. To myself I said, "It's not leading anywhere." It was ...

Prof. Cohen-Almagor: You didn't say this to Peres? 
Joel Singer: When you meet someone and you think he's ugly, you don't say that he's ugly, you say ... . You look better now."

Prof. Cohen-Almagor: Okay, no criticism?

Joel Singer: I may have provided criticism but you ask me about the first meeting.

Prof. Cohen-Almagor: The first meeting with Shimon Peres yes.

Joel Singer: $\quad$ You see, I forget because they called me again. I certainly provided constructive criticism sometime during my first two trips to Israel. As soon as I came back to the United States, they called me again. I flew back; I came to my office the next day after I flew back. Came into the office, sat down, the phone rang and they said, "Can you come again?" And then I flew again the next day, and stayed like for three days or maybe four days. If you ask me about my reaction to the document during the two meetings together, I would say yeah, I provided constructive criticism.

Prof. Cohen-Almagor: Again it was Peres not Rabin?

Joel Singer: $\quad$ No, then they wanted me to meet with Rabin.

Prof. Cohen-Almagor: That was the second time?

Joel Singer: $\quad$ Yeah. I mean, it is like they wanted to take me to Rabin because apparently, Rabin at that time, maybe on the day I flew back told them, "Stop the meetings. That's it. Shut down the Oslo channel."

Prof. Cohen-Almagor: This was after you returned from Jerusalem?

Joel Singer: I think it was when I was on the plane.

Prof. Cohen-Almagor: Rabin told them to stop. 
Joel Singer: I think that what happened was, they needed someone to look at it as they submitted it to Rabin for review or something; or maybe they submitted it to him earlier but they told him, "It's done, now is the time for decision." Something happened which I can reconstruct-- but I need to really think hard-- that caused them to both (1) ask someone external to look at it, and provide an opinion, and (2) tell Rabin, "It's time for decision." Because they concluded it is time for decision. It was being elevated and Rabin said, "Shut it down."

Prof. Cohen-Almagor: Why? Sorry to push you on that, but it's not clear to me. If they took the trouble to invite you to come to Israel, and then you think that they came to Rabin and said, "Well, now it's time for decision." Probably that Shimon interpreted you're saying that actually it's okay to continue otherwise it won't go to Rabin. It would stop.

Joel Singer: It happened at the same approximate time. Or maybe I'm confusing the timeline because I started flying back and forth, and back and forth.

Prof. Cohen-Almagor: You killed your entire family I understand. [as excuses to leave the Washington law firm and fly back and forth to Israel and Oslo]

Joel Singer: $\quad$ Yes. How do you know that?

Prof. Cohen-Almagor: I do my homework.

Joel Singer: $\quad$ Okay, never mind. So up to that time, the meetings with the PLO were done at a low level by two academics, and deniability was maintained. There was then a feeling that it's time to decide which way to go. Is this an academic exercise or is the Government of Israel taking over? However, things don't happen neatly in the real 
world; they don't immediately go from black to white. There is always a grayish area.

They sent Uri Savir- a government employee- to Oslo before they showed the document to me; so that was one elevation of informal discussions to formal discussions. Then they showed the draft to me, then they told Rabin, "It's time for decision." Now, when I say "then," and "then" and "then," maybe they told Rabin it's time for decision earlier and it just took him a few days to decide to shut Oslo down. Maybe l'm mixing it and it happened just the next week but in late May-Early June 93, there was a shifting of the gear from academic nongovernmental discussions, followed by Rabin and Peres, but still maintaining deniability, to assumption of responsibility to the back-channel track and taking the lead by the government. It didn't happen in one day; it happened in a few days, perhaps three weeks.

Part of it was Rabin telling Peres, "Shut it down." And I think, that Peres needed me to come back to Israel to talk with Rabin. So, the group consisting of Shimon Peres, Yossi Beilin and the other Oslo group members was considered by Rabin as a group that you cannot trust. I assume that, previously, somehow, Rabin was drawn into the Oslo process without giving it a lot of thought because it was kept at a low level and done by academics and no decisions were required of him. And I think that when he felt that, "Okay, now is the time for decision." His reaction was, "Well, wait a minute. Wait a minute. This is not just another meeting, I need to consider: 'Do I want it? What about the coalition? What about the elections? Where are we going?" So what do you do? You say, "Stop. I need more time for thinking." And then they brought me in, I think. But I didn't know then that it was happening. It didn't necessarily happen in this order but it happened in this context. This is why I think they needed me.

Prof. Cohen-Almagor: Now, Rabin knew you of course? 
Joel Singer: I I worked with Rabin for many, many, years in the army. I was his international law lawyer.

Prof. Cohen-Almagor: $\quad$ Okay, so he trusted you? You were not part of the rest ...

Joel Singer: $\quad$ Trusted not ... I wasn't ...

Prof. Cohen-Almagor: You were not part of the rest.

Joel Singer: We didn't go together to the movies. I was a professional person with expertise in these matters, someone that was raised and educated in the military, in the defense establishment, so we thought the same way. That's on the one hand. On the other hand, I was not one of the Blazers.

Prof. Cohen-Almagor: Okay, so you come to see Rabin, what did you tell him? You read the document ...

Joel Singer: $\quad$ No, before that, they asked me to write, to give them some written comments on the process which again, I wrote in my hotel in handwriting. And I have always been a diplomatic person; so again, as I told you, I wanted to give this process the best positive characterization, like you know, you live in England, teachers never tell students, "Oh, you're an idiot. Go fuck yourself." They tell the parents, "Your child is improving, and he can really do a lot more. He needs to try more but he's really showing improvement..." So I was positive.

Prof. Cohen-Almagor: You were positive? So you provided comments but they were positive comments?

Joel Singer: Negative comments written in a positive manner. Comments conveying my criticism but in a constructive manner and this is what I remember. For instance, they had an idea of putting Gaza under international mandate like the Palestine Mandate and I thought that was not a good idea for a number of reasons that I 
can elaborate, but it will take me a couple of hours. There was something else that they wanted to do and I thought was not a good idea which I forgot. I mean, many years have passed ...

Prof. Cohen-Almagor: Yeah.

Joel Singer: $\quad \ldots 25$ years. I also thought that the document needed many improvements. I think that I said something like that: "From what I heard from Hirschfeld and Pundak, it's promising what they told me, but I don't see it written in the document. Hirschfeld and Pundak informed me that the PLO representatives said so, and they said so, and they promised that and that, and I said, "Fine, but where is it? I know it's a Declaration of Principles, not an agreement but even a Declaration of Principles should reflect what the PLO representatives said if they indeed said it." Shimon Peres wanted to take me to Rabin for a meeting that included just the four of us: Beilin, Rabin, Peres and I. And actually, that was the group that met throughout the process; sometimes with Beilin, sometimes without, but it was Rabin ...

Prof. Cohen-Almagor: Savir was not there?

Joel Singer: $\quad$ No, never. It was Rabin, Peres and I, with Beilin often but not always joining... And I explained this to Rabin, exactly as I'm telling it to you. I said, "I think it's an interesting exercise to talk with the PLO. You have the Washington discussions with the nonPLO Palestinians, over there, there is a complete stalemate, because these Washington discussions were suspended for several months. The non- PLO Palestinian delegation was controlled by the PLO. The PLO was sitting in the next room and giving them instructions so the non-PLO delegation was like a puppet that you put on your hand and the puppet 'talks' but the PLO's hand is playing the puppet. So the PLO was the puppeteer and the non PLO Palestinian delegation was the puppet. And, in any event, there are no negotiations." 
So there, in Oslo, the PLO was signaling to Israel, "Talk with us and we can do business with you." And, if what I heard from Hirschfield and Pundak correctly represented what the PLO was saying in this back-channel, then these positions were better to Israel than anything I had heard before and it's worth pursuing. But I said, "I don't see those positions in the document. I mean I hear them, I believe them that they're not just inventing this, but it should be written there." So Rabin said, "Okay, can you fix the document?" Just like that.

Prof. Cohen-Almagor: Did he want to scrap the document?

Joel Singer: $\quad$ Say it again?

Prof. Cohen-Almagor: Did he want to scrap the document? Did you suggest to scrap it altogether?

Joel Singer: $\quad$ No.

Prof. Cohen-Almagor: No?

Joel Singer: In fact, Yossi Beilin took me aside and said, "Listen Joel, this document is almost done. It's $98 \%$ done so if you find something here that is really, really bad and needs correction, then go ahead and suggest it. But you cannot start from scratch. We have invested many months. It will all fall apart. So yes, feel free to make corrections but don't start from scratch." And Rabin too, didn't say, "Okay, write a new agreement. He said, "Okay, fix the document."

Prof. Cohen-Almagor: What happened?

Joel Singer: $\quad$ Now as a lawyer, I can tell you that it's much easier to write a good document from scratch than to correct a bad document. It's like you're an engineer, and someone built the Pisa Tower and stopped and then he comes to you and says, "Okay can you fix 
it?" At the same time, as an experienced negotiator, I know that when I'm negotiating with someone regarding a text developed by that someone and he loves his own wording that I think is not written in good grammar or style; yet I will just deal with what is important to me so that he does not walk away. And l've done that in my life as a lawyer before. This is what I do, I negotiate.

And any agreement that is negotiated, unlike poetry that you write on your own, or literature, you don't negotiate; perhaps with your editors or your selected friends that agree to read it and provide comments, but when you negotiate, you have your draft and you have that other side's draft, and you need to come up with a compromise document. In Oslo, it was a bit more bizarre because the Israelis came to me after they concluded the document with the PLO and said, "Well, fix it. If you think it's necessary, but do not exaggerate." And even the little fixing that I did made me public enemy number one because I attempted to introduce what I thought were important fixes. Both sides didn't like my changes, but I think the Israeli side did not like them even more than the PLO side.

Prof. Cohen-Almagor: You said you did little fixing?

Joel Singer: $\quad$ Yeah, that the little fixes that I introduced $\ldots$

Prof. Cohen-Almagor: It was little?

Joel Singer: $\quad$ Yeah. I would have written it from scratch completely different but then, there would have been no agreement; so I can see the point from both sides. In any event, even my little fixes they hated. You just ask me a question I'm telling you what happened.

Prof. Cohen-Almagor: Okay.

Joel Singer: $\quad$ So I sat in my hotel, they wanted me to fix it there and then and I said, "Okay, I need to understand what's going on. I've been out 
of Israel for more than four years. I know that there were negotiations going on in Washington and there was also the Oslo back track ..." I forgot to tell you, the idea was to take the Oslo agreement, to complete it and then to send it back to Washington so that each party will instruct its Washington delegation to sign it in Washington. The back track people were supposed to remain unseen. So I said, "I want to see what was going on in Washington because they spent almost two years- since the Madrid process started. Let me see what they were doing there." So they brought me lots of binders of transcripts and summaries of meetings and I sat in my hotel...

Prof. Cohen-Almagor: Sorry, how far back? [00:27:05]?

Joel Singer: $\quad$ Since it started.

Prof. Cohen-Almagor: Since Oslo started?

Joel Singer: $\quad$ No. Madrid.

Prof. Cohen-Almagor: Madrid? Wow!

Joel Singer: $\quad$ So I wanted to see all the Washington discussions; what was happening in Washington, and I just sat there, for one full day and read all the transcripts of the Washington discussions from day one. I don't think that any of the Oslo negotiators did that.

Prof. Cohen-Almagor: No, they didn't see that l'm afraid.

Joel Singer: $\quad$ Hirschfeld (or maybe Pundak) told me once: "You know, we were reading Yedioth Ahronoth and Haaretz, cutting stories about the Washington DC discussions and this is what we knew when we were working in Oslo. They had no background. And also on the Palestinian side, Hassan Asfour was the only one that knew what was happening in Washington because he was the PLO's political negotiations guy. His English, however, was poor, really poor. 
They sent him to a course to improve English after the Oslo agreement was signed. And Abu Ala was there, the economic guy. He didn't deal with politics and there was a third guy who was Abu Ala's assistant. None of them was familiar with the Washington negotiations.

\section{Prof. Cohen-Almagor: Al Kurd?}

Joel Singer: $\quad$ Yeah, but someone else replaced him later. So I spent the whole day and I realized that nothing really happened in Washington except that there were some agreed phrases that I kept in my mind. And also, I brought with me years of experience from the Begin Autonomy Negotiations. I was one of the chief participants in the Israeli delegation. I was the representative of the Israeli Army in the Begin Autonomy Negotiations. Every document that was created by the Israeli side was either written by me, or reviewed and corrected by me, or written with my participation. There was no Autonomy agreement reached but there were lots and lots of documents.

And then I felt, "Okay, how do I fix it? Because it's not that anyone told me how to fix it, they just told me, "Fix it." But they didn't say, "Okay, we, the Foreign Minister (who was previously the Prime Minister and also who was previously the Minister of Defense) and the Prime Minister (previously the Minister of Defense) ask you to fix it, and this is how you will fix it. You do this, you do that ..." No, they just said, "Fix it."

So I sat in the hotel and I said "Okay, l'll just use all the positions taken by the Begin Government during the 1979-1982 autonomy negotiations and adjust them based on what I know that the Labor opposition party during the autonomy discussions supported. Because I thought that would be the position of Rabin and Peres if they thought about it. 
Let me tell you a story. One day when I was in the Foreign Ministry, already the Legal Advisor, we had every morning, when we were in Israel, a meeting, a short meeting: Shimon Peres, Yossi Beilin, Uri Savir, myself, Avi Gil and another one, every day we would sit and decide how today is going to look like.

Prof. Cohen-Almagor: Sorry, when was that?

Joel Singer: $\quad$ 1993-1995, when I was the Legal Advisor, Shimon Peres was the Foreign Minister, every day when we were there, a short meeting, half an hour. "Okay, these are the main issues for today". I don't think that it has ever been done or that it is being done now. This is how you need to run a ministry. "These are the important things for today. What do we do about them?" And then instructions, "You do this, you do this." You know what is happening in the world and how the Foreign Ministry of Israel reacts to the world.

So one day, there was a discussion and someone said, "The land that Israel confiscates in the West Bank ..." And I said, "Israel does not confiscate land in the West Bank, those are temporary seizures of land for military purposes." And Yossi Beilin, who sat next to me, looked at me. His face expressed a mixture of admiration, contempt, amusement and a few other emotions. "You know Joel ..." He whispered to me, "... I listened to you and realized, you are not expressing the Israeli positions, you are the Israeli positons." Because I wrote all the important cabinet decisions regarding those issues for 20 years. I wrote all the answers of the Minister of Defense to Sheiltot in the Knesset. I participated in all the negotiations; I was responsible for the law in the West Bank, and Gaza, in the Golan Heights, and Southern Lebanon and the Sinai when Israel was there. Relations with the Red Cross, with United Nations forces.

All of that information was in my head; so I was very familiar with the Israeli positions on all of those issues, and I just adjusted them. I 
said, "Okay, I'll take the Begin positions. I know what was the Labor Party's criticism so l'll adjust those positions and this is how I will fix the agreement. But before I presented a modified agreement to Rabin and Peres, they first said, "Go to Oslo. Meet with them, ensure that what Hirschfeld and Pundak are saying, its correct." That was the first step. Hirschfeld and Pundak went one day before me and Uri Savir to tell them who is joining the Israeli team and prepare them for the plan that I would be asking them questions. The idea was that I would prepare a list of questions

Prof. Cohen-Almagor: How many?

Joel Singer: $\quad$ A lot, dozens.

Prof. Cohen-Almagor: Hundred?

Joel Singer: Dozens.

Prof. Cohen-Almagor: Hundred?

Joel Singer: $\quad$ No, but probably with sub-questions. You have to understand, I'm a lawyer. This is why I keep saying, I'm a lawyer. When I interview a witness, the lemon that sits before me will have no drop of juice left in it until I understand what was going on. But it was orchestrated because I knew that they were going there the day before me and I told Hirschfeld and Pundak, "Tell them that I'm coming to ask them questions. And based on their answers to my questions, a decision will be made by the higher echelons in Israel as to whether or not to elevate the Oslo talks." My strategy was, I wanted them to know that it's important, that that was their chance, the only chance for them to answer those questions and that is like a test. That was orchestrated by me.

Prof. Cohen-Almagor: Okay. 
Joel Singer: $\quad$ Then I came there and they didn't like, obviously, that suddenly they were being "interrogated." But it was all orchestrated and they tried to impress me with good answers and I just sat there and took notes of what they said. And then I fixed the agreement based on their answers. After reporting back to Shimon Peres about the results of this meeting, I went back to the United States. With my notes of what they said, with my knowledge of all the Israeli positions on these matters, based on the many years in which I participated in the autonomy negotiations, which helped me determine how the autonomy should look like, I adjusted all of this to the Labor Party's positions, and then I knew what I should write. But the next question was, how to write it and not to cause everything to explode in the next meeting.

So I came back to the United States after I reported the results. I was a volunteer. I lived with my family in the United States. I didn't move to Israel, I was just travelling with some luggage. For the next three months I was flying back and forth. It was Washington, Oslo, Jerusalem, Oslo, Washington, Oslo, Jerusalem for three months. This is how I lived, constantly travelling with a luggage. At the beginning, I took with me just one or two pairs of shirts and underwear and then I realized that sometimes, you fly for two days and you end up staying five days or more.

Prof. Cohen-Almagor: And your law firm was tolerant of all this, three months like this?

Joel Singer: $\quad$ This is why I had to kill ...

Prof. Cohen-Almagor: Multiple people.

Joel Singer: $\quad$... everyone in my family but ... You know at some point, they understood that something was going on and ...

Prof. Cohen-Almagor: But they gave you the leverage? They were tolerant? 
Joel Singer: I told them that I'm doing something for the Prime Minister of Israel.

Prof. Cohen-Almagor: Okay. And you never became an official employee of the Foreign Ministry?

Joel Singer: $\quad$ Not during this period. Only after the Oslo agreement was initialed.

Prof. Cohen-Almagor: Do you think it's correct? That you are taking such responsibility and you're a volunteer actually based in Washington?

Joel Singer: $\quad$ That was inherent in conducting deniable negotiations on a backtrack. These were not formal negotiations. Rabin and Peres wanted to maintain the deniability. I'll now go back to a document that I wrote to Shimon Peres regarding the first draft of the Oslo agreement that was shown to me with some ideas, and criticism- constructive criticism-- on my first or second trip to Israel. Its title was something like, "Comments regarding the draft agreement between Israel and The PLO. "It was like two pages with the letterhead of the hotel. And when I showed this to Yossi Beilin, he said, "No, no." He took a liquid wipeout and said, "Let's wipe out the word "PLO." Write "Palestinians." You give us this document, we will file it here, we don't know what's going to happen with the Oslo discussions, we don't want any document that will have any reference to the PLO in the Foreign Ministry. He said, "Write Palestinians." I said, "Okay." Wiped it out and wrote Palestinians.

These were not official negotiations; just a couple of academics with someone, a former government employee (me), exchanging ideas with the PLO. That was the truth but, when the government took over the discussions, it didn't change the composition of the Israeli team. You can ask, "What about Hirschfeld and Pundak? 
Why were they there? Why do you focus only on me? What about them?"

Prof. Cohen-Almagor: Yeah, two academics and a lawyer from Washington.

Joel Singer: $\quad$ Yeah. Anyhow, is it good? That's the way it's done all over the world. Do you know how World War III was prevented? The threat of a nuclear World War III during the Cuba missiles crisis ended through the back-channel services of a journalist.

Prof. Cohen-Almagor: I didn't know that.

Joel Singer: Go back and read the history books regarding how the backchannel discussions that prevented World War III from occurring were conducted by Bobby Kennedy using a journalist to talk with someone at the Russian Embassy.... That was a back-channel. A journalist. And who did BiBi use with Syria? Mr. Cosmetics (Ronald Lauder).

Prof. Cohen-Almagor: So you are saying that actually, there's nothing wrong in such a composition. Actually it can work.

Joel Singer: $\quad$ The wrong part was that Uri Savir was also there. I mean how stupid can you all be? If you want to maintain this as an informal back-channel why Uri Savir is there? And if Uri Savir is there, why use all of those non-governmental clowns: Joel Singer and the others? You must decide: are you here or are you there? It's like the joke about someone on a weekend. Someone knocks on his door and he opens the door, he's completely naked but wearing a bowler hat, gloves and a Papillion (bow-tie). So the visitor asks him, "Why are you naked? He says," Well, it's a weekend, so I thought no one would come." "So why the bowler hat and the Papillion and the gloves? ..." He said, "Well, I thought maybe someone will come, after all." So this is how it looked like. But life is strange. This is life. Things don't fall squarely into drawers. 
After I reported to Peres and Rabin about what happened I went back to Washington and then sat in my office here, and said, "Okay, now I have to fix it. I have the ingredients." I took notes, careful notes of what they said. I read the Washington transcripts of the two years of discussions. I had in my head all the discussions about the autonomy under Begin. I knew exactly where the Labor Party disagreed with the Likud. I knew the US positions because it made proposals how to close the gaps between the Israeli position and the Egyptian position, because in those days it was Egypt not the Palestinians that negotiated the autonomy agreement with Israel. The Camp David agreement was with Egypt not with the Palestinians and, during the following four years (1979-1983) the autonomy discussions were conducted with Egypt and the United States, So I knew the US positions, the Egyptian positions, the Israeli positions, the Labor Party positions; as well as what the PLO told me in response to my questions. I took careful notes to the dozens of questions, those questions were supposed to help me fix the agreement but then I could not write it from scratch. Writing it from scratch, would have been perfect from Israel's perspective, but it would have been a non-starter, and Yossi Beilin told me not to write a new agreement.

So I left the bad English untouched. I said to myself, you don't want to spend energy and you have only that much that you can do, so let's just focus on the important issues, leave the language alone, so it's not the best grammar. Focus on the important things: from Rabin's perspective (and mine), security was the most important part. Leave alone all the economic projects that were, oh, my God, they spent half of their time in Oslo talking about agriculture. It's important but on a range of 1 to 10 (and I'm not underestimating the importance), if one is the most important consideration (security) then agricultural cooperation is here (pointing at a below 5 location on the range). 
On this, it was very difficult for me, being between Peres and Rabin. I would have wanted Rabin to talk and tell me, this is what I want you to do. As for Peres, I knew what he wanted because he talked about it all the time in our meetings but he didn't instruct me to write it down in the agreement. He told me and the other team members: this is my vision. This is where i want it to be. I want to do this, I want to do that, and he told me right away from the beginning: I want to have the PLO move its $\mathrm{HQ}$ from Tunis to Gaza and to have armed Palestinians maintain security there and the only question was how many armed Palestinians would be allowed to enter. That was subsequently discussed between Peres and Rabin in my presence. How many of them would be allowed in? All of them, just a few, up to a cap?

And I knew that the plan was that this agreement was supposed to be signed in Washington by the existing non-PLO delegation with the PLO not being part of it. So I came with an idea from day one. I said that there was a need to have a mutual recognition agreement between Israel and the PLO. That was something like Cato the Elder, I kept saying from day one: "You cannot pretend. You cannot talk with the PLO and pretend it's not happening. It will leak out. And once it leaked, then you cannot go to them and ask for concessions. Do it now."

But the Foreign Ministry team told me, "Don't raise it." They did accept my other piece of advice to not put Gaza under the administration of the United Nations. I made this recommendation because I knew it was not going to happen. Also, I thought it's bad for Israel because I wanted to maintain freedom of action for Israel for security purposes in the autonomous areas. And I knew that once you place it under the United Nations, it could be a whole new ball game. Perhaps, they should have done it after Israel withdrew from Gaza under Ariel Sharon; then, it might have 
been a better time to put Gaza under the United Nations but not in Oslo, when the idea was autonomy. Anyhow, they accepted it.

The other idea of mutual recognition with the PLO they said, "No, don't raise it." Much later, I had to beg for permission to raise this idea with the PLO as my own personal idea. Shimon Peres didn't want me to raise it with Rabin. Finally, after I begged and begged, he agreed and Rabin agreed to allow me to raise it as my personal idea and ...

Prof. Cohen-Almagor: The mutual recognition?

Joel Singer: $\quad$ Yes, and Peres didn't like it, Rabin didn't like it, and Arafat didn't like it. No one liked it. Only me.

Prof. Cohen-Almagor: Why Arafat didn't like it?

Joel Singer: $\quad$ Because as part of the Mutual Recognition Agreement, he had to make many concessions to Israel, to stop the Intifada, to stop the armed struggle, to agree that the Israeli-Palestinian conflict will be resolved only through negotiations, and not through force, and to cancel the Palestinian Covenant. Early on, I developed a paper in Hebrew about that and Peres said, "Don't show it to anyone. Stop!" He thought that, these Israeli demands required too much of the PLO.

He wanted the Oslo agreement to succeed and he thought that if I raised this it will be like throwing a monkey wrench into the Oslo wheels because it will be too much for them to swallow. And Arafat indeed didn't want to swallow it and Rabin didn't want to recognize the PLO because he was thinking about his coalition. And, in any event, both Rabin and Peres at that time, wanted the Oslo agreement to be executed, signed with non-PLO Palestinians, so the PLO was not supposed to be part of it and yet, Peres told me that his vision was that, once the autonomy 
was established, to invite the PLO to come to Gaza. This was the environment within which I had to navigate.

So the word PLO is not in the Oslo agreement because it's not supposed to be signed with the PLO. For this reason, there is also no room for mutual recognition. The PLO is just behind the scenes but you do want them to take control of the security in Gaza immediately after the agreement is signed, but we are not yet calling them the PLO. We'll deal with it later. I am asked to fix the agreement. But just the important things. So what I did was, I said, "Okay, some of it I have to fix in the agreement but then I created a second document called Agreed Minutes. Behind the Declaration of Principles (the OSLO agreement), you have a second document, the Agreed Minutes, which essentially says the opposite of what you see in the Oslo agreement.

Prof. Cohen-Almagor: And they're part of the agreement?

Joel Singer: $\quad$ Yes.

Prof. Cohen-Almagor: I didn't know that.

Joel Singer: $\quad$ Of course, because this is how I devised it.

Prof. Cohen-Almagor: And was it published, the minutes?

Joel Singer: $\quad$ The Agreed Minutes are both signed by all the parties and published everywhere. It's very legalistic. Essentially, the things I wanted to really change in the agreement, I just put them in the Agreed Minutes, so as not to make too many changes in the already agreed draft Oslo agreement. Yet, I still created a lot of animosity and arguments such as, "You can't make all of those changes at the last moment. ... Because of you, all the effort that we invested will go down the drain..." And I could have attempted making even more drastic changes but I didn't want to cause the discussions to collapse. As a new comer I had to feel what was 
going on, to adjust, and look for how I can find the balance between having the cake and eating it. Putting all the important things there, one way or another, and then not causing it to collapse, and ultimately it happened.

Prof. Cohen-Almagor: What are the lessons from Oslo? What are your lessons? If you can tell me the positives and negatives.

Joel Singer: It all depends on what level of scrutiny or what aspect of the Oslo process you want to look at. And also, the Oslo agreement is a lot of things. Those are two words but behind it there are several issues: Should Israel and the PLO have started talking to one another? That's a very important change that occurred. Yes or no? And it's completely different from the question: Should those two parties have established an autonomy? Is autonomy a good idea or a bad idea? Maybe they should have done something else. It's a completely different question.

Third, the use of a process where you only agree on the need to negotiate important issues but you leave those important issues to be negotiated later; recognizing that you cannot agree on them now, but you still want to do something to create a mechanism, is it good or bad? And I can go on and on, and I can give you 10 different aspects of Oslo that each of them can be the subject of treatises. So which one of them do you want me to talk about? And I can go on.

Prof. Cohen-Almagor: The last one, the last one.

Joel Singer: Last one?

Prof. Cohen-Almagor: Leaving all the important issues aside. I mean, as I see it, Oslo is like a gentleman agreement with a tweak. So we discuss things but we're not discussing violence and terrorism on the Palestinian side, we're not discussing the settlements on the 
Israeli side, and more or less we are willing to tolerate your terrorism and incitement of violence?

Joel Singer: That's not Oslo. "We're willing to tolerate ..." That's what you say. Prof. Cohen-Almagor: Well, okay, so now you say it.

Joel Singer: $\quad$ There is nowhere in the Oslo agreement, any statement, "We are willing to tolerate terrorism." On the contrary.

Prof. Cohen-Almagor: Actually I was quoting Shlomo Ben-Ami, these are his words.

Joel Singer: $\quad$ Well, Shlomo Ben-Ami ...

Prof. Cohen-Almagor: Its tolerating by not filling the gaps, allowing this to happen. Joel Singer: $\quad$ Okay, I don't want to tell you what I think about Shlomo Ben-Ami because I don't think a lot about him. I may have met him once in my life. So I don't know what to say but if this represents what he said, then I don't want to react to this. The Oslo agreement, the way it was written, not originally but once Rabin took over and when I say once Rabin took over means approximately when I was brought in and started meeting with him every ...

Prof. Cohen-Almagor: April 1993?

Joel Singer: $\quad$ Yeah. Every draft was seen and approved by him and I heard from him not once, not twice, not three times: "It's all about security. I don't care about any other aspect of the Oslo agreement," he said. "It's all about security. If there is security, the agreement will succeed. If there is no security and it's otherwise perfect, the agreement will fail." That's Oslo for me. Now, how it was subsequently implemented, I'm a lawyer, as I told you, I'm not a politician. I don't run things. I can only tell you what the approach was when writing the agreement. You can write a 
perfect agreement and then not implement it. So if you ask me about what Oslo says, don't ask me questions (because I'm a lawyer) about implementation, that's not my job.

Prof. Cohen-Almagor: So you think security was handled correctly in Oslo? It was addressed correctly?

Joel Singer: $\quad$ Correctly is a different question because I told you about the problems. If I wrote the Oslo agreement from scratch, it would have looked different. However, the way I fixed it, under Rabin's instructions, I think it addressed correctly and I will tell you why. Part of how I fixed it, especially in the area of security is that, and you may want to read something that I wrote in English way back.

Prof. Cohen-Almagor: $\quad$ You have it? I will more than happy to ...

Joel Singer: $\quad$ Yeah, it was my analysis of the Declaration of Principles. It was published in ... I don't know, l'll find it and send it to you.

Prof. Cohen-Almagor: Thank you.

Joel Singer: $\quad$ This is how I wrote the agreement and it's very important that you understand it because that's at the core of the security issue. What is an autonomy? An autonomy is that Israel is the source of authority, the current source of authority in the West Bank and Gaza. And Israel gives authority by transferring listed areas of responsibility to the Palestinian autonomous government and therefore by definition, whatever is not transferred, remains in the hands of Israel and that was a way of fixing issues without poking them in their eyes.

Because you can write in the agreement, "Israel will do this, and Israel will do that and Israel can do ..." And then start negotiating it at the last minute after they spent the whole day negotiating something else and say, "I want the agreement to say, "Israel will do this, Israel will do this and Israel can come and demolish 
houses and deport people and have military bases and can go and impose curfews." That's one way of saying it, right? The other way of saying it is to say nothing. Just, "Here's what we transfer to you. Everything else remains with us." You don't need to argue. You don't need to negotiate.

Prof. Cohen-Almagor: So it's better for implementation then?

Joel Singer: We have it, it's ours. And now, if someone decided not to do it, that's maybe a good decision, maybe a bad decision, but Israel had the authority in security matters. Now there were two troubles. First of all, it's one thing to write it, and it's another thing to do it. You give them autonomy in the Gaza City, you go out of the city but remain in other parts of the Gaza strip, with authority to go back into the city, if necessary for security reasons. But the fact that you have the authority to go back, doesn't mean that it's easy to go back, because you may need to fight, and so that leads us to another question: Was the autonomy idea a good idea? Maybe we should have jumped immediately to a state.

Prof. Cohen-Almagor: Nobody spoke about two state solution?

Joel Singer: $\quad$ No, the only game in town then was autonomy, and had always been the only game in town since 1977, after Sadat came to Israel. Begin then created his Autonomy Plan, which I reviewed before it was provided to the United States, and the idea was we are not going to withdraw completely. We will only redeploy the IDF outside of the populated areas. We will give them autonomy with a strong Police force. Was that a good idea? There was a consensus in Israel that that was the solution. Under Begin, it was supposed to be the permanent resolution; under the Labor Party, it was supposed to be a phase before changes in sovereignty. There were questions about where the borders would pass and what the role of Jordan would be, but it was clear to the Labor Party that there would be sovereignty there and not Israeli 
sovereignty. But still, the autonomy was the initial phase under the Labor Party government. Was that a good idea? I don't know. I think the jury is still out on that.

Can you jump immediately to statehood? Let's say you spend 10 years negotiating statehood and then the PLO comes from Tunis and you withdraw to the final line and give them statehood. Is this a good plan? And only then will Israel see what happens with missiles and all of that, rather than having a long trial period where it's an autonomous area and you can go back and fix it and start again. It's much more difficult to invade a sovereign state than go back to an area where you retain your overall security authority, which is what we did in Oslo and I didn't invent it, I mean, I just wrote it. That is the essence of autonomy.

Autonomy is something that is limited in scope and subject to someone else's overall authority. And the only question was the scope of the autonomy. Wide autonomy? Narrow autonomy? Only dealing with the sewage and trash collection? Or also getting wider authority? But either way, when you put the Likud here and the Labor there, everyone supported autonomy, just with a different scope. Is it a good idea? No. Is there a better idea? I don't think so.

Prof. Cohen-Almagor: Oslo was a success story as far as you?

Joel Singer: I don't know.

Prof. Cohen-Almagor: You don't know?

Joel Singer: I don't know. I can only talk about the legal aspects of Oslo. You have to be a historian, you have to be an expert in Middle East politics and a philosopher and psychologist and a few more areas of expertise and have a perspective of a few more years, maybe another 50 years, to consider this question, was Oslo a good 
idea? And also: in comparison to what? In the real world, you don't have good and bad. In the Middle East, the solutions you have to choose from are bad, terrible, disastrous, stunningly bad, etc. Those are the real choices.

Prof. Cohen-Almagor: I see that you looked at your watch. I'll ask you two questions and then l'll go.

Joel Singer: $\quad$ No, I gave you until 11:30.

Prof. Cohen-Almagor: What's the time now?

Joel Singer: $\quad$ It's now 11:04.

Prof. Cohen-Almagor: So we have still have a time oh, excellent. You participated in the discussions with the Palestinians in Oslo, you flew back and forth, you asked them all these questions, they didn't like all this thing. Then, there was another meeting in which they come up with many, many, many questions.

Joel Singer: $\quad$ Not many but $\ldots$

Prof. Cohen-Almagor: But some.

Joel Singer: $\quad$ They felt the need to reciprocate but it was done just to check a box just to show me. It was ...

Prof. Cohen-Almagor: It was not a $\ldots$

Joel Singer: $\quad$ No.

Prof. Cohen-Almagor: Okay. Then there was the agreement that was signed, well more or less signed ...

Joel Singer: $\quad$ First I gave them a new draft and I said, "Okay, here is a new draft." And they said "Oh, oh ..." 
Prof. Cohen-Almagor: Now, how different was the new version because you said it was little fixing, and how far was the little ...

Joel Singer: $\quad$ The little fixing ...

Joel Singer: $\quad$... almost caused the negotiations to collapse.

Prof. Cohen-Almagor: So it was not that little.

Joel Singer: $\quad$ For me it was little in comparison to what I wanted to do. For them, those little fixes were so dramatic that they almost stopped the negotiations.

Prof. Cohen-Almagor: But they swallowed the pill at the end?

Joel Singer: Ultimately they understood that if they wanted to pass from discussions with two academics to negotiations with the government of Israel, they needed to swallow this bitter pill.

Prof. Cohen-Almagor: You were presented as Rabin's man. Were you Rabin's man? Because you were of course employed by the Foreign Ministry. Peres may ...

Joel Singer: $\quad$ This is how I built it. I told ...

Prof. Cohen-Almagor: You built it?

Joel Singer: Yeah.

Prof. Cohen-Almagor: Not them?

Joel Singer: Who are them?

Prof. Cohen-Almagor: I don't know. Savir or Beilin, Shimon ...

Joel Singer: $\quad$ No, no.

Prof. Cohen-Almagor: $\quad$... Yair Hirschfeld whatever. 
Joel Singer: No, no I told Hirschfeld and Pundak to tell the PLO representatives

Prof. Cohen-Almagor: That you are coming?

Joel Singer: $\quad$ To tell them that they needed me to like the draft agreement if they wanted Rabin to like it and approve it. They needed to make me happy, that was the message. I mean, not in so many words but there is always a tongue in check in a lot of what I say to you so the point was that I took something that had more than a grain of truth in it, because it was indeed possible that Rabin would not let the Oslo agreement go forward if he had not have me ensuring him that his desires were being reflected in the agreement.

It doesn't mean that if it wasn't me, it could not have been someone else. You don't know how history would have developed. You can never say, if this didn't happen then that wouldn't have happened. They could have found maybe someone else that Rabin would have trusted but it so happened that it was me. There was a lot of history between me and Rabin working together in the Ministry of Defense. But this was blown up a bit to allow me to get from them explanations and statements regarding the PLO positions that I then used in fixing the agreement. When they saw the new draft that I brought and said, "What, what, what have you done ...?" I said, "Remember, I met with you, and you told me this. This is what you said ..." So this was the game.

And you have to understand that life is difficult, life is not what you read about in the books or see in the movies. They would have liked to promise the Israelis the world but sign a different document, if they would have signed it at all, because sometimes they don't sign what they're supposed to sign. I caught them not signing documents, pretending to sign and not signing, but they needed documents that would... 
Prof. Cohen-Almagor: What? Pretending signing and not signing?

Joel Singer: Yeah.

Prof. Cohen-Almagor: What do you mean? Is it a game? What is it kids? I mean, what is that? I don't understand that. When did it happen?

Joel Singer: $\quad$ Don't you remember when the Gaza-Jericho ...

Prof. Cohen-Almagor: Cairo?

Joel Singer: $\quad$... agreement was signed in Cairo, I caught Arafat not signing the maps attached to the agreement.

Prof. Cohen-Almagor: Yeah, yeah.

Joel Singer: $\quad$ As Arafat signed first, I was standing there and watching. $\mathrm{He}$ signed the agreement and he was supposed to also sign the maps that were attached to the agreement, but he didn't sign the maps.

Prof. Cohen-Almagor: Because he realized that there were problems with the maps?

Joel Singer: $\quad$ He didn't realize, he decided not to sign them because the maps showed the extent of the autonomy, Gaza and the Jericho area. But Arafat didn't like the agreement that the two parties reached regarding the size of the Jericho area, so he didn't sign the maps. That's Arafat. And I was supposed to then go up on the stage and help Rabin sign. I was just standing there and watching Arafat because I had witnessed previous cases when they didn't sign agreements.

Prof. Cohen-Almagor: Well, it happened before?

Joel Singer: $\quad$ Yeah, yeah. That's life, that's life, my man. So I saw he didn't sign and then Rabin came, he was second, and I came and stood next 
to Rabin. My role was simply to tell him, "Sign here, sign here." And I told him, "I just saw Arafat ..." (You know it was on the stage with all the cameras, so I was whispering to Rabin in a discreet manner) "... he didn't sign the maps," and then I showed him, "You see? You're supposed to sign here, but he didn't sign." So he said, "What should I do?" I said, "We have to stop, don't sign." $\mathrm{He}$ said, "Is the agreement valid without this signature on the map?" I said, "No, because the map is part of the agreements." And on the stage, there was a big show and arguments and Mubarak shouting at Arafat ...

Prof. Cohen-Almagor: "Sign ya Kalb", on camera, "sign".

Joel Singer: $\quad$ And then I negotiated a statement with the PLO behind the scenes that Israel will reconsider the size of Jericho Area... Anyhow, how did I get there? I was talking about something else.

Prof. Cohen-Almagor: Building around the answers of the PLO delegation to Oslo when they protested against your new document.

Joel Singer: $\quad$ So I said, "But we met here, and I took notes; you said it. I didn't invent it, you said it." So what they wanted is to have a document that they sign, if they sign (this is how we got into this side story), a document that would be vague and something that they can present to their people allegedly showing that they didn't give up anything. They wanted us to accept their oral promises that everything would be okay. This would have allowed them subsequently to deny what they said. "We didn't sign it, we just said it." And then you know "he said, she said," They wanted to maintain this ambiguity and I just told them, "No, no, if you want this agreement to go forward, you must sign what you said. I don't want two versions. One that is signed and the other one that is just whispered in our ears." And they didn't like it. I understand them. I also would like to have the cake and eat it. 
Prof. Cohen-Almagor: Was there any lawyer on their side?

Joel Singer: $\quad$ Remember, they brought me after the agreement was done.

But after I redrafted the agreement, they brought in an Egyptian lawyer. The former legal advisor to the Egyptian Foreign Ministry that was my counterpart, not my formal counterpart because I was in the Army then, but I was working with him on the Begin Autonomy ...

Prof. Cohen-Almagor: What's his name?

Joel Singer: $\quad$ Taher El-Shash.

Prof. Cohen-Almagor: An Egyptian lawyer?

Joel Singer: $\quad$ An Egyptian lawyer that worked for Egypt during the Begin autonomy discussions, but at that time the Egyptians represented the Palestinians. So he was familiar with the autonomy issues and he reviewed it. We actually met there and talked and he advised them on the Oslo agreement issues... Taher el-Shash, Taher elShash. How I remember his name? Because during the autonomy negotiations, the head of the Israeli delegation who was the Director General of the Ministry of the Interior from the Mafdal, Haim Kuberski. Haim was a religious orthodox Jew and Eli Rubinstein was there and there was a lot of Yiddishkite. And Taher el-Shash was not just the lawyer but the head of the Egyptian delegation at that time. So Kuberski would call him, "vetaher libeinu... Taher el-Shash." That was his nickname only internally, within the Israeli delegation and so I met Taher elShash in Oslo.

Prof. Cohen-Almagor: Tell me what you think about settlements. What was the issue there? What was the intension of the Israeli government? That Israel is going to continue the settlements, empower the settlements, what's there? 
Joel Singer: Whose position?

Prof. Cohen-Almagor: You said that you constructed a document, but didn't get any instructions so actually it was you I presume that ...

Joel Singer: $\quad$ No, what was your question just repeat it.

Prof. Cohen-Almagor: What was the idea about, your idea about the future of the settlements?

Joel Singer: $\quad$ The future? The future when?

Prof. Cohen-Almagor: The present and the future. Near future, very near

Joel Singer: $\quad$ Near future okay.

Prof. Cohen-Almagor: Was the issue of settlements addressed correctly in Oslo?

Joel Singer: It was addressed consistent with the position of the Labor Party.

Prof. Cohen-Almagor: Which is?

Joel Singer: $\quad$ Which is that, as I understood it, and as it was then, I mean it may have changed, it did change.

But as I understood it then, the Labor Party was against putting settlements in any area that will not ultimately be part of Israel in their vision of where the border should be and therefore there were the Labor Party settlements and there were the Likud Party settlements. The Labor Party settlements were in the Gush Etzion area, in the Jordan valley, and in the Jerusalem area, and perhaps near the Green line in other places where there was a need, for security purposes, to make changes in the 1967 boundary.

In other words, in their view, settlements were not an objective in and of itself, religious or national, but rather means to create facts 
on the ground following the old MAPAI, actually pre-MAPAI, Labor movement whatever the name was from time to time, Dunam veod Dunam, Ez veod Ez, if this is where we want the border to be, for security purposes, we need to build settlements there, in order to establish facts on the ground, and then when the time comes, this will establish our borders.

We should never build settlements in areas that we don't envision will be in Israel and we should never build settlements in areas heavily populated by Palestinians. But they were not against settlements per se. Therefore, what I put in the Oslo agreement reflected this position and it was that the settlements stay in place during the autonomy; no change, and that as part of the permanent status negotiations, the parties will negotiate the future of the settlements as well as the borders with the idea that if it is the Labor Party that will negotiate the permanent status, which I thought would be the case, then all the settlements that were not on the correct side of the border will have to be evacuated after the permanent status agreement was accomplished and those that will be on the Israeli side of the border will stay in place.

In other words, the Labor Party settlements will be part of Israel and maybe with some corrections because there were a few settlements too large to evacuate, but all the others will go but not during the five ear autonomy. This is what I did, the same way which I did with Egypt in the 1979 Treaty of Peace. Remember, there were three years of interim status in the Treaty of Peace with Egypt.

During that period, all the settlements in the Sinai remained in place, all of them, during the three-year period between the signing of the treaty until the withdrawal to the international border, and then because the withdrawal was to the international border, all of them were withdrawn. In the Oslo agreement, I just 
saw five years instead of three years, and not returning to the international border but to some adjusted line, you know, the armistice line adjusted for security purposes according to whatever Rabin and Peres and the government would want the border to be.

Prof. Cohen-Almagor: So now we're in White House, we have this wonderful ceremony in the White House? You are in Israel, you are now an employee of the Foreign Office?

Joel Singer: $\quad$ First of all, I was in the White House in the ceremony. I was there.

Prof. Cohen-Almagor: Okay after that yeah.

Joel Singer: I lived in Washington.

Prof. Cohen-Almagor: Yossi Beilin says in his book that he was trying to get you a contract in the Foreign Ministry.

Joel Singer: $\quad$ Yes, while I was doing this back and forth they wanted me to come back but they had to deal with the then existing legal advisor and find him some new position and when the Oslo agreement was signed, I was still living in Washington.

Prof. Cohen-Almagor: So when did you return to Israel as an employee of the Foreign Office?

Joel Singer: $\quad$ The Oslo agreement was signed ...

Prof. Cohen-Almagor: September.

Joel Singer: $\quad$... September ...

... 13. Formally, beginning in September 1 , I got the job but I didn't move to Israel immediately because all my family was in the United States. I didn't have a house to move to in Israel. Practically, I started working in Jerusalem on October 1. 
Prof. Cohen-Almagor: Okay.

Joel Singer: $\quad$ After the agreement was signed everyone returned to Israel I was already the legal advisor but all my family was here. I took a few days' vacation to shut down the operation, to go back to my office and to tell them, "Yeah, I'm leaving bye, bye. You have all the paperwork to do." And stayed with my family, my wife and kids remained there a few months after me. I came back to Israel and lived with my brother for a while, until we went into a house after the family returned ...

Prof. Cohen-Almagor: In 1994?

Joel Singer: $\quad$ No, that was the end of 1993.

Prof. Cohen-Almagor: $\quad$ Okay so you were in Israel from late 93? Joel Singer: $\quad$ Yeah.

\section{Conclusion and Aftermath}

What are the lessons from Oslo? What are its main achievements? While we may not be able to make conclusive conclusions, here are some interim observations.

Oslo was a breakthrough. For the first time, Israelis and official representatives of the Palestinian Liberation Organisation sat with each other to talk peace. Until that point, Israel refused to recognize the PLO. Israeli leaders invented Palestinian representatives that were mere strawmen. Strawmen are just that, strawmen. They did not represent the Palestinians. They served the Israeli interests. Consequently, they were unable to deliver. For peace, you need to talk to your enemies; otherwise, Israelis and Palestinians will continue to meet each other mainly in the battlefield. 
Oslo saw some success. Not a great success but limited success because both Israel and Palestine wanted to harvest some fruits. Both sides wanted to reach a deal, even a limited deal. This determination is very important. When both sides do not wish to come out empty handed. When both sides are determined to open a new road, even a limited road, both sides will remain committed until they see some results. There were moments of crisis in Oslo but the Israeli and Palestinian negotiators were determined to overcome those moments. They did not wish to break the process, pack the suitcases and return home with nothing. Such a commitment is essential for successful negotiations.

Convivial atmosphere is conducive to negotiations. Both sides wanted to be in Oslo. Neither side felt coerced to come to the table. The negotiators learned to know each other and they developed closer relationships as they spent more hours together. Chemistry and relaxation in the company of each other is important to generate good will. When people feel comfortable with each other, they would be willing to invest in understanding the other's point of view. Then both sides are willing to devote energies in seeking creative solutions, in putting their heads to the task of finding compromises in places where they thought none existed.

Another lesson has to do with the identity of the negotiators. There is so much that you can do with academics. They may jumpstart a process. They have the good will, the zeal, some experience and some clever insights. But successful and meaningful negotiations require expertise. Professional negotiators are irreplaceable. The fine details require knowledge and attention that only experts can bring to the table.

Another lesson relates to the mediators. The Norwegians were well aware of their limitations. They were careful not to assume responsibilities that they would not 
be able to carry. They saw their role as facilitators. The Norwegians could not press both sides, and they knew it. For a more conclusive deal, the Israelis and the Palestinians need the Americans. The Camp David summit between Israel and Egypt is a model to follow.

Being away from the public eye in Oslo was conducive for the talks. Total secrecy was not. Leaders need to prepare their people, and preparation requires time and some knowledge. Leaders would not like to be perceived as thieves in the night. When the Israel-PLO negotiations became public knowledge, this was shocking news for some people who found it difficult to digest the news and to live with them.

Equally important is to be aware of spoilers and address their challenge. Leaders should not ignore spoilers because then the spoilers will become more adventurous and daring. Spoilers wish to break the rules of the game and, indeed, the game altogether. They will exploit any weakness to do this. Both Israel and Palestine did not prepare their people adequately, and did not address the spoilers as they should have. Many believe that Yasser Arafat tacitly even encouraged spoilers, holding the symbolic olive leaf in one hand, and a sword in the other. Rabin dismissed his spoilers and paid the highest price a person can pay: his own life. On the fateful night of 4 November 1995, a night that many see as the sign on the wall for Oslo's collapse only just over two years since the signing of the accords, an Israeli zealot aimed to reverse the trend of history. He saw some success.

Still, Oslo paved the way for some collaboration between Israel and the PLO on important civilian and security matters. Meetings between Israelis and Palestinians, attending to problems together and finding solutions together is not novel anymore. Israeli and Palestinian grass-root organisations operate together in the West Bank, trying to bring about a more peaceful reality. These are small steps. They are like 
scratches on the wall. One scratch is hardly noticeable. But many thousands of scratches may change the face of the wall altogether. 